\title{
NOTES ON COMMUNICATION RESEARCH EPISTEMOLOGY AND METHODS
}

\author{
Cicilia M. Krohling Peruzzo
}

\begin{abstract}
This text weaves some aspects of research in Communication starting from the philosophy of knowledge as a basis for understanding science. It aims to discuss the issue of scientific research in the epistemological perspective, to consider the importance of scientific methodology in its methodical and technical dimensions, as well as to reflect on aspects of the research carried out in Latin America and more specifically in Brazil. It is a theoretical approach based on a non-systematic and non-exhaustive literature review. The existence of thematic and methodological diversity is examined, as well as the apparent tendency of the research to focus on the novelty, mainly in regards to elements related to technology, as object of study. The urgency of strengthening research in Communication is also considered, both theoretical and empirical, and the necessary advance in the design and description of research methods and techniques when presenting results and analyzes.
\end{abstract}

\section{KEYWORDS}

Empiricism; epistemology; methodology; research in Communication

\begin{abstract}
Resumo
Este texto tece alguns aspectos da pesquisa em Comunicação partindo da filosofia do conhecimento como base para se entender a ciência. Tem como objetivos discutir a questão da pesquisa científica na perspectiva epistemológica, atentar para a importância da metodologia científica em suas dimensões metódicas e técnicas, além de refletir sobre alguns aspectos da pesquisa realizada na América Latina e mais especificamente o Brasil. Trata-se de uma abordagem baseada numa revisão teórica não exaustiva e não sistemática. Considera-se a existência de diversidade temática e metodológica, além da aparente tendência da pesquisa em enfocar a novidade, principalmente de elementos relacionados à tecnologia, como objeto de estudo. Também se comenta sobre a premência do fortalecimento das pesquisas em Comunicação, tanto as teóricas quanto as empíricas, e do avanço necessário no desenho e na descrição dos métodos e técnicas de pesquisa quando da apresentação de resultados e análises.
\end{abstract}

\section{Palavras-Chave}

Empirismo; epistemologia; metodologia; pesquisa em Comunicação

\section{INTRODUCTION}

This text weaves some aspects of the research in Communication, starting from the philosophy of knowledge as a basis for understanding science, in order to provoke reflections and debates, but without any pretension of addressing all the components that concern it. It aims to discuss the scientific research in Communication under the 
epistemological perspective, to be attentive to the importance of scientific methodology in its technical and methodical dimensions, as well as to reflect on aspects of the trends and quality of the research carried out in Latin America and more specifically in Brazil. Rather than answers, we intend to promote debates and ask questions for future reflections.

First of all, it seems to us important to recognize the existence of methodological and thematic diversity under the research in Communication umbrella. The studies span from themes related to means of communication, i.e. means of information, such as radio, newspaper, television and cinema, to communication environments on the Internet with research about cyberculture, technological devices, interactivity, media and online social networks. Nonetheless, they also encompass organizational communication and public relations; advertising; public communication; interpersonal and group communication; popular, community and alternative communication, among other forms and means of communication. Based on a non-systematic and non-exhaustive literature review of scientific production in publications and papers presented at congresses, as well as on the bibliographical research carried out for this article, we can affirm that the emphasis has been given to studies on Journalism and, more recently, on cyberculture, as a result of the emergence of the Internet and the elevated concern with the technological mediation in the cultural and communication phenomena. Approaches related to cultural identities, imaginary and narrative representations either in or from the media, partly under the influence of the theoretical perspective of cultural studies, are also present in the Communication studies.

In a like manner, we observed some trends in the course of the research in Communication. One of them is the fad, or a fashion approach related to an emergent phenomena - especially due technological development, major events ${ }^{1}$ or the arrival, in Brazil, of theories already in evidence in other countries, mainly from the United States or Europe. Television is an example of this kind of approach. For a long time, it has been widely regarded as a unit of observation, both critically and to understand its logic of entertainment and journalistic production. New technologies, especially from the emergence of the Internet and the constitution of the cyberspace, are attracting many researchers recently. It can be seen through the large number of studies on cyberculture and on the new configurations and uses of media and online social networks presented in conferences and published in journals and books. The cyberculture has even become a sub-area of Communication that has its own researcher association ${ }^{2}$. Another trend, in part linked to the previous one, is the marked research interest in emergent phenomena. Previously it was the Internet itself, its emergence and as a technology that provides a space of freedom of expression, sociability, etc. Nowadays, the gaze turns to the innovation of its configuration (Big Data, algorithms, robots, smart technology systems...), the changes

\footnotetext{
'Interest, for instance, in studying the treatment given by the press to the case of the impeachment of the former president Dilma Rousseff. Another example: after the large public demonstrations in June 2013, in Brazil, which made the role of alternative media more evident, although they have existed for decades, the interest in studying them becomes more pronounced.
}

${ }^{2}$ ABCiber - Associação Brasileira de Pesquisadores em Cibercultura [Brazilian Association of Researchers in Cyberculture]. See: https://abciber.org.br/ 
that the internet provokes in cultural standards, the potential of participation and shares, and so on. These are, perhaps, characteristic aspects of an area of knowledge whose pillars change rapidly, marked by a complex and dynamic interdisciplinarity. In this hybrid and shifting context of the Communication field, another trend observed by us for years is the emphasis on investigative approaches that only touch communication instead of treating it as a central research object. This is the case of studies whose analytical axes are based on technological, cultural and procedural parameters more sensitive to other areas of knowledge which cannot be seen from the communication point of view or from the communication process involved in the investigated phenomena.

Regarding the methodologies used in the Communication research, it is not new that the appropriation of techniques and methods developed in other areas of knowledge occurs, even though there is an effort to "bring" or adapt them to the specificities of the Communication area. We are referring to techniques and methods such as hermeneutic, historical research, ethnography, content analysis, discourse analysis, participant observation, discussion group, focus group, questionnaire, and interviews. However, some of these methodologies have more affinity with the objects of the Communication such as content analysis, discourse analysis, unstructured interviews and focus group, in addition to the development of more characteristic methods and techniques used in reception and audience research such as the creation of electronic meters and the reception observations at the time of exposure of people to television content - soap operas, for instance.

\section{SCIENTIFIC RESEARCH: THE NEED FOR A STEP BACK}

The discussion on the research in Communication brings an underlying issue: science. Are we really doing science? What characterizes a scientific research? The debate is neither recent nor simple nor finished. It is based on the philosophy of science and the theory of knowledge, whose boundaries are difficult to visualize and they refer to the epistemology of science. As discussed by Blanché (quoted in Santos, 1989, p. 19), the epistemology is a "second order reflection on science, a meta-science". Thus, the term epistemology is not used as a synonym of theory, since it refers to the deep understanding of the course of the scientific research nature, of its epistemic bases. Jean Piaget $(2011, \text { p. } 20)^{3}$, elevates the epistemology to the category of discipline which "aims to interpret science as a result of human mental activity or, likewise, explaining how the real thoughts of men can produce science as a coherent system of objective knowledge". Therefore, in the case of the research in Communication, from the epistemological point of view, Communication is investigated as an object of knowledge, both at the theoretical level and at the level of epistemic and methodical processes from which the knowledge is generated and that also indicate the elements of its consistency and validation. This has been undertaken by researchers at an international level, such as Calhoun (2012), Fuentes Navarro (2008, 2015), Galindo Cáceres (2008), Morágas Spà (2011) and Martín Serrano (2007), and also in Brazil, but in a smaller scale, since the predominant

\footnotetext{
${ }^{3}$ He attributes the co-authorship of this sentence to E. W. Beth.
} 
tendency is directed at the understanding of the institutionalization of the field. Accordingly to Lopes (2010, p. 29), there is "neglect of epistemological issues in the empirical research of the Communication, a result of the deficient formation in research and of the instrumentalized inheritance of science, possibly the same one which identifies Communication as 'applied' social science in the institutional classification".

Returning to the science point, there are different paths to generate scientific knowledge from epistemological positions and conceptual frameworks. We will briefly address the empiricism in opposition to visions which question some of its assumptions, such as those of considering its research parameters as the only ones capable of leading to science. It finds support in the positivism, an epistemic current that defends the supremacy of the object in relation to the subject in the research process. This corresponds to a conception of science inherited from Physics, an exact science that would translate the scientific postulates valid for every field. Augusto Comte (quoted in Triviños, 2012, p. 33), important systematizer of the positivism, has even referred to Sociology as "social physics", as a discipline devoted to the study of social facts.

At this level there is the defense that scientific knowledge would be generated from the methodological objective research processes, supposedly neutral (to examine the reality in an uninterested way), able to privilege the object over the subject, i.e., to sensorially capture the knowledge that exists in the object without the "contamination" of the subject, the researcher. In the words of González (2007, p. 48),

empirical positions privilege the side of the object over the subject. They assume the reality is outside the subject and it exists independently of him. His knowledge is summed up in observing, recording and writing, in all detail and without personal contamination, the characteristics of the object.

Some characteristics of this epistemic perspective are: attributing to science the function of "seeing to predicting"; taking reality as formed by isolated parts; not being interested in the phenomena causes; rejecting the metaphysical knowledge once considered speculative; believing that "true" knowledge is that one empirically verifiable (Triviños, 2012, pp. 35-37), hence the valuation of the experiment and the hypotheses that can be verified by empirical observations, deduction and methods and techniques derived from statistics and mathematical calculations. This current considers, as already mentioned, that only the parameters developed in the epistemic sphere linked to empiricism would be valid and able to generate scientific knowledge and, therefore, they should be followed by every field of knowledge. It advocates that observation must be subordinated to the observation of facts as the sole object of science, once reality contains the "truth" and the work of the researcher 4 is to grab it. This is a predominant position in the history of science, despite being questioned in its universalist perspective at the same time. Paul Feyerabend (1977), in the last century, was one of the critical exponents of rationalism

\footnotetext{
${ }^{4}$ For now on we use the gender masculine, without disregarding the gender equality in these matters.
} 
and of the rejection of universal methodological rules 5 . Among other epistemologists, Jean Piaget (2011) and Rolando Garcia $(2002,2008)$ stand out as critics of empiricism, understood as a conception of science. Ultimately, there are different currents of thought, which are allocated in epistemological conceptions of scientific labor, different among them because they depart from divergent assumptions about worldview and science, such as positivism, phenomenology, structuralism, systemic focus, dialectical historical materialism, constructivism and genetic epistemology.

Without entering in the specificities of each of those modes of conceiving science and producing knowledge, which also indicate the taking of a stance that precedes a research and the bases of the path to be taken in the process of generation of knowledge, we do only a counterpoint to the prevailing view based on empiricism with a synthesis of views which refuses to see science from this perspective, as the only one valid and applicable to every field of knowledge. This point of view can be found in different approaches, but mainly in dialectical historical materialism, constructivism and genetic epistemology. It is a critical perspective that question, for instance, the idea of scientific neutrality which is supposed to exist in empiricist studies, once they are based on objective methodologies. In fact, there is no neutral stance, even in the methods they believe they are, because every variable and every type of approach imply choices that come from worldview. The theoretical-methodological and epistemological approaches depart from an epistemic position, from an alignment with certain interests and views of society. Orlando Fals Borda (2013, p. 302) warns: the value of science varies "accordingly to objective interests of the social classes involved in the formation and accumulation of knowledge, i.e., in its production". After all

science is a cultural product of the human intellect, a product that responds to concrete collective needs (...) and also to objectives determined by social classes which appear as dominants in certain historical periods. Science is built by applying rules, methods and techniques that obey a certain type of rationality conventionally accepted by the minority community made up of people called scientists, who, because they are human, are precisely subject to motivation, interests, beliefs and superstitions, emotions and interpretations of their specific social development. For this reason, there can be no absolute value attributed to scientific knowledge. (Fals Borda, 2013, p. 302)

The production of scientific knowledge changes in conformity with the conditions of its production and the demand for knowledge by societies in certain periods. When its parameters considered as infallible are questioned, it is because there is a search for new forms of research, other types of knowledge and new types of scientific results able to offer different explanations and to understand the problems posed by life in society. This

\footnotetext{
${ }^{5}$ At the bottom, there is a concern that methods and methodologies may inhibit the generation of knowledge. Gumbrecht, H. U. (quoted in Sodré, 2014, p. 288) recommends: "do not believe in any 'method' or (even worse) methodology - not because methods or methodologies are intrinsically bad, but because they prevent one from thinking independently and from enjoying its intellectual freedom in a dimension which does not allow rigid regulations".
} 
is perhaps the reason why Carlos R. Brandão (1999, p. 225) states that "the possibility of transforming a scientific practice, that has so long concealed its political being, into a practice that for precisely call itself political in its origin and destiny claims to be scientific". In this sentence, one can notice the affirmation of social segments demand of other types of research such as those that can help to understand the reality of subalternized classes and also to collaborate to the transformation of the basic socio-organizational praxis, without a promise of neutrality, but seeking the scientificity. This is the case of the participant research, for instance, especially the action research in the context of the popular social movements of Latin America. However, it is clear that the aforementioned method does not have its applicability limited to emancipatory movements, since it is used in several areas of knowledge (Thiollent, 1981, 2003) and with different kinds of purposes, from the business world to Education, Psychology, Computing, Agronomy, and Communication.

In brief, it is claimed the recognition of scientificity in research which disagrees with "traditional" canons. We are not saying that they are neither valid nor important, on the contrary, but we believe they cannot be taken as the only parameters to measure scientificity. It is not acceptable that the standards applied to exact and health sciences, among others, serve as parameters to all sciences, including humanities and social science. There are domains of social and cultural life (Minayo, 2011) that can be better understood and interpreted through qualitative research once they are located in the universe of meanings, values, aspirations, and attitudes. In other words, there are environments and problems that can be better understood from non-exact, non-experimental and nonquantifiable concepts, methods and techniques.

In reality, in the history of science, there is a continuous process of research methodologies and epistemological development in defiance of the understanding of the most diverse phenomena of this world. It is a path in which both quantitative methodologies - from print to online questionnaires, electronic meters to quantify audience etc. - and qualitative ones - from the participant observation to the observing participation and from the latter to the participant action research (Peruzzo, 2016), from ethnography to netnography - are improved and developed. In addition, semi-structured and in-depth interviews, such as oral history, life history, family history, focus group and discussion group, remain always current. They are open methodologies and also capable of generating scientific observables and knowledge. The idea of loss of scientificity in studies that do not follow the parameters of empiricism is prejudiced. However, we are not referring to the empirical research itself, once not all empirical research is empiricist. The term empiricism applies, as already mentioned, to assumptions such as what one needs to know is allocated in the "pure" empirical referent (object). In other words, accordingly to Jorge González (2007, p. 50), to the empirical perspective, "the reality is real and it is captured through sensory experience, which we perceive as nervous irritations of varying intensity and duration", on which deductions and generalizations are made.

Empirical research can be traced from different methodologies and conceptual frameworks. The narrow view of empiricism cannot recognize the possibility of intelligent distancing and rigor of the researcher in research processes, even with methods and 
techniques of an open nature. There is research which does not promise neutrality, but it generates knowledge. What matters is to develop a science that can penetrate areas imperceptible to the techniques of exact, health and biological sciences. This does not mean that the necessity and importance of investigations of quantitative, experimental and observational nature are denied for certain research problems. Each investigative problem requires techniques and procedures consistent with what one wants to know. The questioning lies in the unidirectionality sought by the hegemonic research perspective.

Science is historical. It moves, advances and changes in conformity with the historical process of civilizations. At times of history, the phenomena of nature were seen as emanating from transcendental powers. At other times one tries to understand the phenomena in the a priori perspective (apriorism), which privileges the subject over the object. That is, the most important thing is not the object, because it is the rational capacity that leads to knowledge. "It is supposed that there are a number of a priori categories, innate through which we know the reality" (González, 2007, p. 49). Finally, the systemic positions pass through philosophical idealism which recognizes "the spiritual principle as primarily and the matter as a secondary aspect" (Triviños, 2012, p. 19), transit through logical empiricism, dialectical materialism and constructivism, among other conceptions. Logical empiricism sediments the epistemological core in the "radical dualism" between "empirical knowledge, extracted from experience from the direct perception of sensory data, and logic, considered language that would coordinate and organize such knowledge by adjusting to the formal rules of language itself" (Garcia, 2002, p. 43). The dialectical materialism conjugates the materialistic philosophy and the dynamic of dialectic in the "attempt to seek coherent, logic and rational explanations for the phenomena of nature, of society and of thought" (Triviños, 2012, p. 51). It is attentive to history, interconnections and the movement that transforms reality. Whilst for constructivism, knowledge "is not only related to the object nor to reason, but it stems from the interaction between subject and object, with emphasis on the subject as producer of knowledge" (Siqueira \& Erdmann, 2007, p. 292). They are epistemological positions that have to do with conceptions of society - for example, the bases of dialectical materialism come from the philosophy of Marxism that sees society as contradictory once constituted from antagonistic social classes -, that guide the scientific view and the methods to be employed.

Ultimately, every research departs from an epistemological position, i.e., from a conception of the world, even if it is not conscious and/or not explicit by its protagonists. Thus, there are questions underlying any definition of research problem. To research for what? What to research? How to research? In the area of Communication, how would one envisage answers to this kind of question?

\section{FOR THE QUALITY OF THE RESEARCH IN COMMUNICATION}

There is no doubt that research in Communication can be taken from different angles. Each of them can lead to instigating reflections and conclusions, but there is a wholeness that challenges the investigation. After all, the field requires reflections 
articulated in several planes and levels of analysis: an ontological one, on the nature of the communication; (...) another level is the epistemological one, which questions communication as an object of knowledge, and evidently, to certain communicators (...) subjects of this knowledge; and, of course, a methodological level, which has to do with the ways in which these objects of knowledge and of definition are formulated as objects of inquiry. But before the methodological level, I believe that it is necessary to reflect on a praxeological level (...), since communication is, in its general essence, a social practice or, as it should be said more accurately, a sociocultural practice, contextualized, historized, crossed by power. (Fuentes Navarro, 2015, p. 12)

In this perspective, one can see the field's object fertility, which with its singularities and, at the same time, its epistemological links, transits in an incessant transience. On the one hand, it is a recent science in a process of fast development, but at the same time, it suffers the technological and social transformations of societies on a daily basis. It is a challenging area because it is very broad and dynamic, with and without borders with other areas of knowledge. That is, the configurations of the praxeological universe of Communication have been changed rapidly in the last decades - from channels to the media and messages -, from communication process - interpersonal to organizational, massive, community, digital and online ones -, from mediatic and live communication environments to virtual one - and so on, which forces to a continuous search for the revision of concepts and theories, their re-elaboration and the formulation of new concepts and theories to analyze the transformations. On the other hand, the area congregates an interesting interdisciplinarity as it permeates and is permeated by other sciences.

What is researched in Communication? Without attempting to answer this question, we only remark that, first, there is a great diversity from the angle of the explored object to the units of analysis and the types of communication processes emphasized. This diversity is one of its richness and, perhaps, of its weaknesses. Simultaneously with the coverage of diverse themes and research objects - even as a reflection of the scope of the area, as hinted in the two previous paragraphs, which make more complex the development of theories, roughly, it also runs the risk of dispersion, of pulverizing themes, of emphasizing the novelties, mainly technological, and the surroundings of the communication processes. It seems to have resistance or difficulties in starting from Communication, of forms, of means and of communication processes as a focus. From our point of view, too much attention is given to underlying aspects, such as sociological, anthropological, cultural, technological, narrative ones, sometimes leaving behind the communication involved in the type of phenomenon analyzed. The fact that up to now there is still discussion on the epistemological plane on what is Communication, what is its object, and whether or not it constitutes science, discipline and field of knowledge is, perhaps, a reflection of this situation. As Melo says (2011, p. 21), "although there is no consensus in the academy about the nature of the object of the Communication sciences, the fact is that, for half a century, a community which research communication 
phenomena has been being structured". Among the diversity of the studied phenomena, in the conceptual scope,

the multiplication of proposals for theoretical reformulation of the Communication studies shows a general dissatisfaction with the current state of the field and the urgency to rethink its foundations and to reorient the practical exercise. They are convergent analyses, although not always complementary, which carry out revisions, redefinitions, restructurings, reinterpretations, and ruptures with analytical categories, conceptual schemes, investigation methods. Nonetheless, they are analyses that revealing the complexity and multidimensionality of the communicative phenomena in an increasingly globalised, multiculturalized and technological world, but also increasingly fragmented and unequal. (Lopes, 2003, pp. 282-283)

Second, the interdisciplinarity which characterizes the Communication processes, the theoretical foundations itself and the structures in which the media institutions are rooted, while strengthening it, makes it difficult to delimit the objects and to establish the demarcation of borders in relation to other areas of knowledge.

Alongside the thematic diversity, there is some methodological disparity in the Communication research, especially in Brazil and other Latin American countries. There are methodologically consistent research in the design of the methods and techniques, as well as in the analysis of the observables and in the forms of presentation of the methodologies used. It seems that stricto sensu graduate courses and research groups have helped to promote advances in this direction. However, there is also elementary research, from a methodological point of view, at least, judging from the papers presented at congresses and published in scientific journals, although it is also an occurrence in dissertations and theses. At the same time, there is a tendency in descriptive minimization of the methodologies used. The superficiality in the description and/or omission of the methodologies used are detrimental to the scientific development of the area. Perhaps this situation is even a symptom of the tendency towards paperism, as Jorge A. Gonzalez (2017) says. The academic pressure for the diffusion of scientific production, accentuated by the current policy on science and technology, leads to the increase in the production of hasty articles and communications on emerging themes and to the approach of partial results of research, instead to a more dense presentation of analysis of completed research.

In this context, the tendency of elaboration and diffusion of studies of first-order prevails, attached to the description of properties and elements of an object. Open semistructured interviews, discourse analysis, documentary studies and bibliographic research are techniques widely used in research of this type, but also questionnaires and content analysis are used as research techniques. However, more in-depth statements on these questions request systematic and national-level investigations.

It is interesting to notice, among other aspects, the trend observed, in a nonsystematic and non-exhaustive way, towards empirical studies - from an empiricist or 
non-empiricist nature -, although there is a challenge in make more complex the object definitions, the methodologies used and the analyses. Signs of the concern about the quality of research in Communication are perceived in lectures, working groups of congresses in the area, dissertations and theses defended in postgraduate programs, especially through the research of the research developed by researchers (Ferrara, 2003; Lopes, 2003; Maldonado, 2003; Melo, 2011; Sodré, 2014) attentive to theories of Communication and the issues of epistemology and scientific methodologies.

In summary, regarding the methodological issue, some challenges approach the research in Communication. It is imperative to improve first-order studies through the use of more complex methodologies in order to improve the descriptions and, at the same time, to understand the communication phenomena in their complexities. Simultaneously, it is urgent to move from first-order studies to the second, third and fourth orders (Garcia, 2002; González, 2007) at the interpretation level, which requires the use of more in-depth approaches. While first order approaches are descriptive of properties and elements, second order approaches are more reflective and able to perceive the relationships between observables and to cross theories. Those approaches that look at the processes and develop an even higher level of interpretation, being able to generate concepts are the third order ones. The fourth order approaches are even more advanced because they develop theories and depart from epistemology leading to the interpretation, analysis and explanation of theoretical and methodological problems.

The choice for a given methodological strategy arises from the research question formulated initially, which in turn comes from the research problem - formulated from a concrete and conceptually problematized practical situation - which one wants to understand. Therefore, the delimitation of the object (not to be confused with the unit of observation) leads to more or less relevant problems. The relevance can be in both the degree of contribution of the results to the development of concepts and theories and in the high level of understanding of complex phenomena, in addition to their importance - in theoretical knowledge and/or its applicability - to social groups and to society as a whole, among other aspects.

To conclude this part, we would like to add that methodologically consistent research goes well with relevant themes. The combination of a complex methodology with a highly relevant research theme for society is one of the important components that justifies investment in research, whether it is a personal effort or public funds. There is a lack of research that could exhaustively analyze the themes, objects and methodologies privileged by the research in Communication, whose results make it possible to evaluate the degree of its importance to the knowledge area and to society. This is another research topic for the future.

\section{APPROACHES AND DIFFERENCES BETWEEN RESEARCH METHODS AND TECHNIQUES}

The definitions of "how to do research", in addition to touch epistemological questions, use to stumble upon doubts about methods and, more precisely, about the 
differences between method and technique, even because these terms are housed in the word methodology. Therefore, methodology encompasses methods and techniques, but the word method is neither a synonym of technique nor of the expression methodological procedures. Method comes from the Greek and is written meta-odós, which means path to go beyond. Meta (to go beyond) and odós (path, way). Thus, method means the path or way of an investigation. This path includes epistemological assumptions (not always explicit), the conceptual framework (theorization) and the methodological framework (methodical strategies and techniques). The research on how these elements are processed is challenging for the understanding of the research in Communication, from the epistemological point of view, once it would indicate the degree of scientific basis and theorization, as well as the course of the research in view of its internal coherence and validation in the field.

Reporting to Gaston Bachelard, Lopes (2010, p. 28) clarifies that epistemology is taken at the level of historical development of science and at the operative level,

as a methodological practice, understanding that the epistemological reflection operates internally in the practice of research. In other words, the principles of scientificity operate internally in the practice of research, since the epistemological criticism governs the criteria of internal validation of scientific discourse (...). This epistemological perspective must necessarily involve external validation criteria, supported by the criticism made by the sociology of science or of knowledge.

Rolando Garcia (2008, p. 71), uses the expression "conceptual and methodological framework" as "the name and surname of the same entity, which contains at the same time an epistemological position, a certain conception of 'reality' (cosmovision), and a modality of investigation".

Starting from these coming notions, and with a pedagogical proposal, we can adopt both expressions "conceptual and methodological framework" and "scientific method", if it suits us, but we should conceive them as having three dimensions: the epistemological, the conceptual-theoretical and the methodical itself, interconnected and inseparable, even though with specific performances.

The epistemological dimension (or epistemic framework) indicates the position in the philosophy of science, the epistemic matrix, or the system of thought from which derive other decisions on the conceptual and methodological options. The epistemological position indicates whether the research is aligned with apriorism, empiricism, constructivism or dialectical materialism, or in other terms with positivism, phenomenology, structuralism, functionalism, dialectical historical materialism or constructivism and its variations, in addition to orienting (not determining) the theoretical basis and guiding the method and the research technical proceeding. The epistemological matrix is chosen by the researcher, and it will always exist, once it reflects a sight, a concept of science and worldview, even if it is not a conscious and deliberate choice. Rolando Garcia (2002, p. 120) is emphatic in saying that the epistemic framework "represents a system 
of thought, rarely explicit, that permeates the perceptions of a given time in a specific culture and conditions the type of theorizations that arise in several fields of knowledge".

The theoretical-conceptual dimension, which has as its roots the epistemic framework - or a system of thoughts, guides and shapes the theoretical basis, i.e., the theorization which works as a basis for the investigation or from which it starts. And, in more advanced studies, it guides the new theorization elaborated. However, even if the epistemic framework conducts and conditions the conceptual framework, it does not determine the content of the theorization that will be specific to each investigation. As Garcia (2002, p. 120) says, "within an epistemic framework there are innumerable conceptual milestones" within a discipline.

The methodical dimension (or methodological framework) refers to the principles and precepts which support the methodology (word that comprises method and technique) that matches and leads to the developed research practices. That is, the method brings together the antecedents (concepts of the world and of science), the theoreticalmethodological basis which supports the research strategy and the techniques that facilitate the practice of research for data generation, information gathering and observables. In other words, on the one hand, the methodical dimension presupposes the theoretical basis starting from concepts that guide methodical conception. On the other hand, the methodical dimension incorporates the instruments of data and information collection such as questionnaire, interview, focus group, direct observation etc.

The methodical conception of action research, for instance, has a set of principles and conceptual delineations that indicate the type and direction of the researcher's insertion in the investigated situation, that is, they signal the macro-methodological strategy of this type of research, which will, in turn, outline the practice of research and the use of techniques.

In this perspective, the methodical framework (methodology) has two components: the methodical strategy (method) and the technique(s). Once more, method is not synonymous with technique, it precedes the technique and will even indicate which technique is most relevant to the development of a particular research. Ultimately, method and technique complement each other, they usually go together and even intersect, but in somewhat different spheres. Techniques are the instruments used to collect information and data, to record observations and to identify observables.

It is also convenient to distinguish between data and observables. According to González (2007, p. 60), it is common, especially in the practice of empiricist research, to call "data" or "evidence" the "configurations of information obtained from objects. When we name it observables, we not only change the name of things, but it is important to emphasize the decisive role of the Subject and their own determinations in the construction of what they will see and judge as theirs objects". Thus, observable presupposes the data plus the interpretation of it.

In general, there is more concern with techniques than with methods and epistemological issues in theses and dissertations in the Post-Graduation Courses in Communication, particularly in Brazil. However, as we have already said, even methodological procedures are not always well described in order to help the reader to understand the 
process by which certain results have been reached and thus can confer internal validity and attest, or not, credibility to the research.

The research will be credible for all that it demonstrates in terms of the seriousness of the research process, the coverage and pertinence of the methods and techniques employed, and the quality of the results, combined with its thematic relevance and theorizing capacity. The relevance will also be noted for the ability to respond to the knowledge needs of the Area, the country and the continent on which it is based.

It does not make sense to do research with the unique intention of generating papers for congresses and/or articles acceptable to be published by foreign journals which even tend to induce themes of interest and modes of expression - just to raise individual scores in academic rankings. Scientific research makes sense when it is done to generate knowledge capable of contributing with subsidies to the society for the equation of its crucial issues, from the problems to the understanding of the historical-political, communicational, economic, cultural and ultimately all areas which constitute that society, configurations. As Paulo Freire (1981, p. 36) says, there is a political character in the scientific activity, and asks: "whom do I serve with my science? This must be a constant question to be asked by all of us".

\section{FinAL CONSIDERATIONS}

To conclude, without concluding, the thematic of this text, so arid and at the same time instigating, we reinforce the existence of the need to strengthen research in Communication, both theoretical and empirical. Along with the delimitation of relevant problems the depth of the epistemic ${ }^{6}$ and theoretical frameworks, and the relevance of the methodological framework are of paramount importance, in addition to implying epistemic clarity and rigorous use of scientific methods and technical procedures competent and capable of responding relevant questions asked.

A relevant research problem tends to generate relevant results, capable of surprising by the novelty and by the depth of the "findings". From our point of view, the research in Communication in Brazil has not surprised much, although there are exceptions. The trends previously discussed reflect the trails of a science, sometimes grovelling in its epistemic contour, objects and methodical anchoring, but in a growing process of constructive qualification. Thus, it is not a matter of asserting whether what is produced is or is not science, but of instigating new research and more meta research. Research that take into account elements of the theory of knowledge and the ontological and epistemological dimensions of the Communication, that focus on communicational objects and care with the scientific methodologies employed. But at the same time, research open to the understanding, respect and appreciation of the different notions of science and scientific methods.

Translated by Denise Maria Moura da Silva Lopes

\footnotetext{
${ }^{6}$ Given the complexity of the epistemological question, in general, the explanation on the epistemic framework is not required in the Brazilian Postgraduate Programs in Communication, which would be desirable at least for the doctoral degree.
} 


\section{BIBLIOGRAPHIC REFERENCES}

Brandão, C. R. (1999). A participação da pesquisa no trabalho popular. In C. R. Brandão (Ed.), Repensando a pesquisa participante (pp. 223-252). São Paulo: Brasiliense.

Calhoun, C. (2012). Comunicação como ciência social (e mais). Intercom - Revista Brasileira de Ciências da Comunicação, 35(1), 277-310. doi: 10.1590/rbcc.v35i1.1108

Fals Borda, O. (2013). La ciencia y el pueblo: nuevas reflexiones sobre la investigación acción (participativa). In N. A. Herrera Farfán \& L. López Gusman (Eds.), Compromiso y cambio social. Textos de Orlando Fals Borda - antologia (pp. 301-319). Buenos Aires: El Colectivo-Lanzas y Letras-Extensión Libros.

Fals Borda, O. (2013a) Romper el monopolio del conocimiento. In N. A. Herrera Farfán \& L. López Gusman (Eds.), Compromiso y cambio social. Textos de Orlando Fals Borda - antologia (pp. 253-263). Buenos Aires: El Colectivo Lanzas.

Feyerabend, P. (1977). Contra o método. Rio de Janeiro: Francisco Alves Editora.

Ferrara, L.(2003). Epistemologia da comunicação: além do sujeito e aquém do objeto. In M. I. V. Lopes (Ed.), Epistemologia da comunicação (pp. 55-67). São Paulo: Loyola.

Freire, P. (1981). Criando métodos de pesquisa alternativa: aprendendo a fazê-la melhor através da ação. In C. R. Brandão (Ed.) Pesquisa participante (pp. 34-41). São Paulo: Brasiliense.

Fuentes Navarro, R. (2015). Desafíos e responsabilidades de los estudios de la comunicación en América Latina. In M. A. Mattos \& M. E. Oliveira (Eds.), Desafios e perspectivas epistemológicas do campo comunicacional: estudos comparativos internacionais (pp. 10-23). Belo Horizonte: PUC-MG.

Fuentes Navarro, R. (2008). La comunicación desde una perspectiva sociocultural. Guadalajara: ITESO.

Galindo Cáceres, J. (Ed.) (2008). Comunicación, ciencia e historia. Madrid: McGraw-Hill.

Garcia, R. ( 2002). O conhecimento em construção. Porto Alegre: Artmed.

Garcia, R. (2008). Sistemas complexos. Conceptos, método y fundamentación epistemológica de la investigación interdisciplinária. Barcelona: Gedisa.

González, J. A. (2015). Por una cultura del conocimiento. In M. Maass; J. Amozurrutia \& J. Gonzalez, Cibercultur@e iniciación en la investigación interdisciplinaria (pp.303-380). Ciudad de México: CNCA/ IMC/UNAM-CEICH.

González, J. A. (2017). Entrevista. Tríade - Comunicação, Cultura e Mídia, 5(9), 246-253. Retrieved from http:// periodicos.uniso.br/ojs/index.php/triade/article/view/3028/2690

Köche, J. C. (1997). Fundamentos de metodologia científica. Teoria da ciência e prática da pesquisa. Petrópolis: Vozes.

Lopes, M. I. V. (2003). Sobre o estatuto disciplinar do campo da comunicação. In M. I. V. Lopes (Ed.), Epistemologia da comunicação (pp. 277-293). São Paulo: Loyola.

Lopes, M. I. V. (2010). Reflexividade e relacionismo como questões epistemológicas na pesquisa empírica em comunicação. In J. L. Braga; M. I. V.Lopes \& L.C. Martino (Eds.), Pesquisa empírica em comunicação (pp. 29-49). São Paulo: Paulus/Compós.

Maldonado, A. E. (2003). Explorações sobre a problemática epistemológica no campo das ciências da comunicação. In M. I. V. Lopes (Ed.), Epistemologia da comunicação (pp. 205-225). São Paulo: Loyola. 
Martin Serrano, M. (2007). Teoría de la comunicación. La comunicación, la vida y la sociedad. Madrid: McGraw-Hill.

Martino, L. C. (2003). As epistemologias contemporâneas e o lugar da comunicação. In M. I. V. Lopes (Ed.), Epistemologia da comunicação (pp. 69-111). São Paulo: Loyola.

Melo, J. M. (2011). Memória do campo acadêmico da comunicação: estado da arte do conhecimento empírico de natureza historiográfica. In M. Barbosa \& O. J. Morais (Eds.), Quem tem medo de pesquisa empírica? (pp. 19-75). São Paulo: Intercom.

Minayo, M. C. S. (2011). O desafio da pesquisa social. In Minayo, M. C. S. (Ed.), Pesquisa social. Teoria, metodo e criatividade. 32.ed. (9-29). Petrópolis: Vozes.

Morágas Spà, M. (2011). Interpretar la comunicación. Barcelona: InCom-UAB/Gedisa.

Peruzzo, C. M.K. (2016. A pesquisa participante, de uma matriz teórico-metodológica às especificidades das práticas investigativas. Paper presented at XIII Congreso da Asociación Latinoamericana de Investigadores de la Comunicación, Univ. Autônoma Metropolitana / Univ.Nacional Autonôma do México, Xochimilco/Cidade do México-México. Retrieved from http://alaic.org/descargas/2016/GT8. pdf.

Piaget, J. \& Garcia, R. (2011). Psicogênese e história das ciências. Petrópolis: Vozes.

Santos, B. de S. (1989). Introdução a uma ciência pós-moderna. Rio de Janeiro: Gral.

Siqueira, H. C. H de \& Erdmnn, A.L. (2007). Construtivismo como método de pesquisa: possibilidade de geração de conhecimentos. Revista de Enfermagem UERJ, 15(2), 291-297 Retrieved from http://www. facenf.uerj.br/v15n2/v15n2a21.pdf

Sodré, M. (2014). A ciência do comum. Notas para o método comunicacional. Petrópolis: Vozes.

Thiollent, M. (1981). Investigación-acción. Chasqui, 1, 76-78. Retirado de http://chasqui.ciespal.org/index. php/chasqui/article/view/975

Thiollent, M. (2003). Metodologia da pesquisa-ação. São Paulo: Cortez.

Triviños, A. N.S. (2012). Introdução à pesquisa em ciências sociais. A pesquisa qualitativa em Educação: o positivismo, a fenomenologia, marxismo.São Paulo: Atlas.

\section{BIOGRAPHICAL NOTE}

Cicilia M. Krohling Peruzzo,holds a PhD in Communication Science from the University of São Paulo (ECA-USP). She did a post-doctorate research at the Universidad Nacional Autónoma de México. Retired Professor at the Federal University of Espírito Santo. She has a scholarship for productivity by CNPq. Author of the books Relações públicas no modo de produção capitalista [Public relations in the capitalist mode of production], Comunicação nos movimentos populares - a participação na construção na cidadania [Communication in popular movements - participation in the construction of citizenship] and Televisão comunitária - dimensão pública e participação cidadã na mídia local [Community television - public dimension and citizen participation in local media]. She organized some book collections and has articles published in several national and 
international scientific journals. Member of the Arts and Communication Advisory Committee of CNPq.

Email:kperuzzo@uol.com.br

Address: Rua Dr. Nicolau de Souza Queiroz, 194 - ap.201, CEP 04105-000 São Paulo - SP, Brazil

* Submitted: 02.11.2017

* Accepted: 15.03 .2018 